\title{
Perilaku Gedung dengan Perbedaan Kekakuan Antar Lantai
}

\author{
Dicki Dian Purnama ${ }^{1}$; Tommy Iduwin ${ }^{2}$ \\ ${ }^{1,2}$ Sekolah Tinggi Teknik PLN \\ 1dicki@sttpln.ac.id
}

\begin{abstract}
One of the frequent failures caused by the earthquake is the soft story. Soft story mainly occurs in office buildings, hotels or apartments which generally have a lobby or area that is intentionally made without walls / dividers, either on the ground floor or the upper floors so the floor's stiffness will be different. The height of the column can also cause different stiffness between floors. This study will compare between the modeling of portal without wall with a higher level at the bottom of the building, the middle of the building and the top of the building, where the high level with smaller stiffness has the potential to be soft story. In this study using ETABS 9.7.2 program with dynamic response spectrum load based on the 2017 earthquake map. Results The structure period of the results of the analysis with the program was obtained at 2.01 seconds. The shape mode for the three PPKBB, $P K B T$ and PKBA building types has met the requirements where in shape 1 and 2 modes the building is translating towards the $x$ or $y$ axis while in shape 3 mode is twisted. The required mass participation ratio value is reached at the $90 \%$ percentage reached at the 8th shape mode for the $P K B B$ and PKBT buildings. While for PKBA it is reached in the 5th shape mode. Deviation values for the three types of building $P K B B, P K B T$ and $P K B A$ are still within the permit limit.
\end{abstract}

Keywords: earthquake, soft storey, spectrum response

\begin{abstract}
ABSTRAK
Salah satu kegagalan yang sering terjadi akibat gempa yakni soft storey. Soft story terutama terjadi pada bangunan perkantoran, hotel atau apartemen yang pada umumnya memiliki lobby atau area yang sengaja dibuat tanpa dinding/sekat, baik pada lantai dasar atau pun lantai-lantai diatasnya sehingga kekauan antar lantai akan berbeda. Ketinggian kolom dapat pula menyebabkan kekauan antar lantai yang berbeda. Penelitian ini akan membandingkan antara pemodelan portal tanpa dinding dengan tinggi tingkat yang lebih besar pada bagian bawah gedung, tengah gedung dan atas gedung, dimana tingkat tinggi dengan kekakuan lebih kecil berpotensi menjadi tingkat lunak (soft story). Pada penelitian ini menggunakan program ETABS 9.7.2 dengan beban dinamik respon spektrum berdasarkan peta gempa 2017. Hasil Periode struktur hasil analisis dengan program diperoleh sebesar 2,01 detik. Mode shape untuk ketiga tipe gedung PPKBB, PKBT dan PKBA sudah memenuhi persyaratan dimana pada mode shape 1 dan 2 bangunan gedung mengalami translasi kea rah sumbu $x$ atau y sedangkan pada mode shape 3 mengalami puntiran. Nilai rasio partisipasi massa yang disyaratkan tercapai pada proesentase $90 \%$ tercapai pada mode shape ke-8 untuk gedung PKBB dan PKBT. Sedangkan untuk PKBA tercapai pada mode shape ke-5. Nilai simpangan untuk ketiga tipe gedung PKBB, PKBT dan PKBA masih dalam batas ijin.
\end{abstract}

Kata kunci: gempa, soft storey, respon spketrum 


\section{PENDAHULUAN}

Kekakuan memiliki pengaruh yang linier terhadap perilaku simpangan/perpindahan. Semakin kaku suatu bangunan maka simpangan/perpindahan yang terjadi akan semakin kecil. Namun struktur yang terlalu kaku juga tidak baik karena mekanisme sendi plastis tidak akan terjadi. Sehingga pada saat terjadi beban yang melebihi kapasitasnya maka struktur akan langsung gagal tanpa adanya indikasi kerusakan. Kekakuan harus tetap mengikuti standar yang berlaku.

Di dalam desain struktur gedung tahan gempa, kolom soft storey dianjurkan agar dihindari karena pada dasarnya akan menimbulkan tekukan yang besar dan perubahan kekakuan yang cukup drastis ${ }^{[1]}$. Ketinggian kolom yang berbeda antar lantai dapat menyebabkan perbedaan kekakuan antar lantai. Hal ini terutama dijumpai pada gedung yang berfungsi sebagai area lobby, lantai mezzanine pada bangunan perkantoran, hotel, dan apartemen. Selain itu banyaknya lubang/void pada lantai dapat pula mempengaruhi kekakuan lantai. Jika mekanisme kegagalan karena soft story terjadi maka akan berefek domino pada seluruh lantai.

Pada peraturan SNI 03-1726-2012 Pasal 7.3.2.2 struktur yang digolongkan sebagai tingkat lunak jika terdapat suatu tingkat dengan kekakuan lateralnya kurang dari 70 persen kekakuan lateral tingkat diatasnya atau kurang dari 80 persen kekakuan rata-rata tingkat diatasnya. Jika kekakuan lateral yang terjadi kurang dari dari 60 persen kekakuan lateral tingkat diatasnya atau kurang dari 70 persen kekakuan rata-rata tingkat diatasnya maka struktur tersebut termasuk ketidakberaturan kekakuan tingkat lunak berlebihan ${ }^{[2]}$.

Dalam penelitian ini dibandingkan perilaku gedung dengan perbedaan kekakuan antar lantai akibat ada pengaruh ketinggian kolom yang berbeda di area bawah gedung, tengah gedung dan atas gedung.

\section{METODE PENELITIAN}

1. Tahap Persiapan:

Pada langkah awal berupa pengumpulan data dan referensi awal yang mendukung penelitian. Penelitian ini bersifat analitis dan mengandalkan analisa komputer yang didukung dengan data standar mengenai aturan bangunan gedung beton bertulang, standar peraturan gempa dan peta zonasi gempa serta standar pembebanan yang berlaku. Khususnya di Indonesia. a. Alat dan Bahan

Alat bantu yang digunakan dalam desain dan analisis struktur adalah program komputer analisis struktur yang mampu menganalisa perilaku struktur gedung. Program yang digunakan yakni ETABS.

\section{b. Konfigurasi Geometris Sruktur}

Parameter-parameter dimensi kolom, balok dan pelat dihitung berdasarkan preliminary design. Sementara untuk denah gedung (Panjang, Lebar dan Elevasi) dapat dilihat pada gambar berikut.

Bentuk gedung dibagi menjadi tiga yakni 1) Bangunan dengan tinggi kolom dua kali lebih besar pada bagian bawah bangunan, 2) Bangunan dengan tinggi kolom dua kali lebih besar pada bagian tengah bangunan, 3) Bangunan dengan tinggi kolom dua kali lebih besar pada bagian atas bangunan.

Selanjutnya perbedaan kekakuan antar lantai pada gedung bagian bawah ditulis (PKBB), perbedaan kekakuan antar lantai pada gedung bagian tengah ditulis (PKBT), dan perbedaan kekakuan antar lantai pada gedung bagian atas ditulis (PKBA).

Jarak antar kolom $\quad=6 \mathrm{~m}$

Jumlah lantai $\quad=10$ lantai

Tinggi lantai tipikal $\quad=3 \mathrm{~m}$ 
Khusus pada tipe gedung PKBB tinggi lantai 1 sebesar $6 \mathrm{~m}$ dan tinggi lantai diatasnya 3 $\mathrm{m}$. Pada tipe gedung PKBT tinggi lantai $1-4$ sebesar $3 \mathrm{~m}$, tinggi lantai 5 sebesar $6 \mathrm{~m}$ dan tinggi lantai 6-10 sebesar $3 \mathrm{~m}$. Pada gedung tipe PKBA tinggi lantai 1-9 sebesar $3 \mathrm{~m}$ dan tinggi lantai 10 sebesar $6 \mathrm{~m}$.
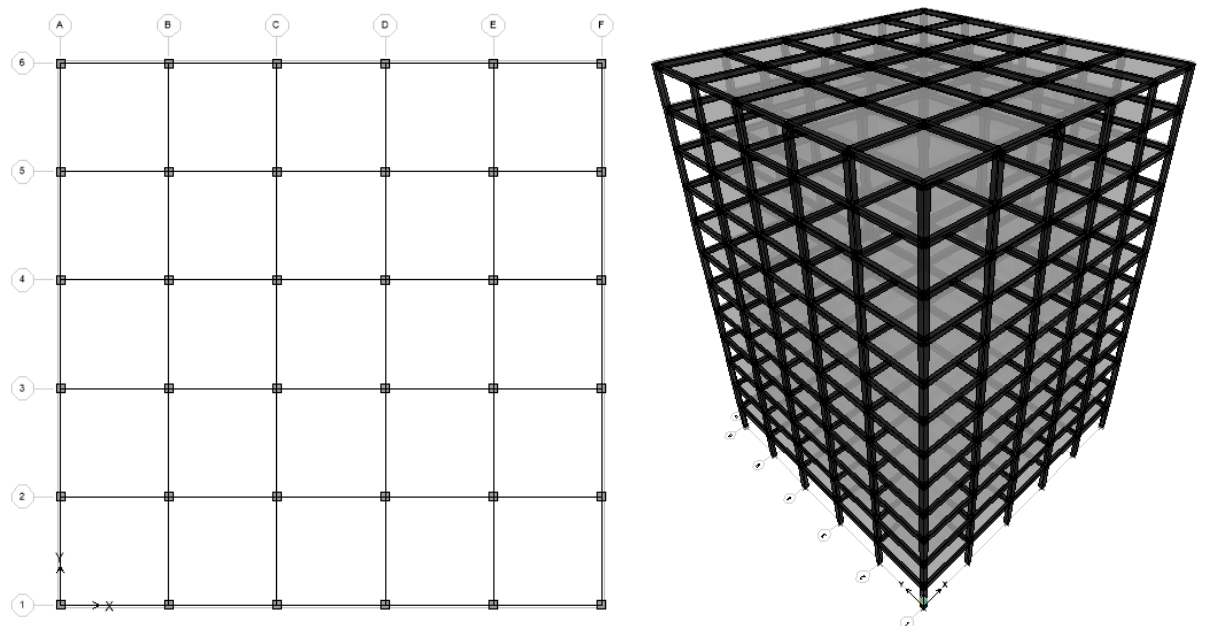

Gambar 1. Denah dan Isometri Gedung

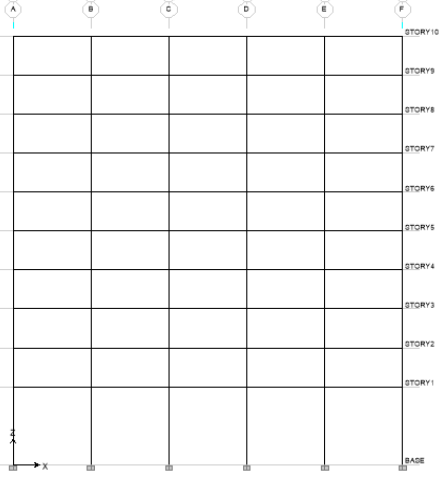

Perbedaan Kekakuan antar Lantai pada Bagian Bawah

(a)

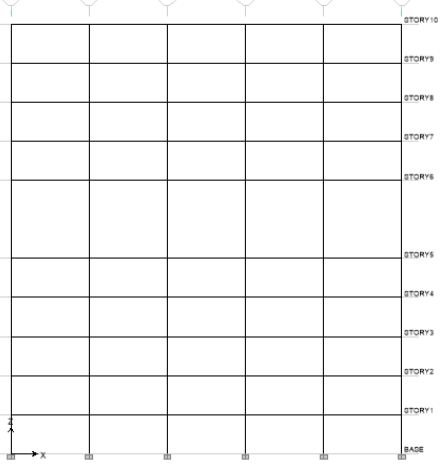

Perbedaan Kekakuan antar Lantai pada Bagian Tengah

(b)

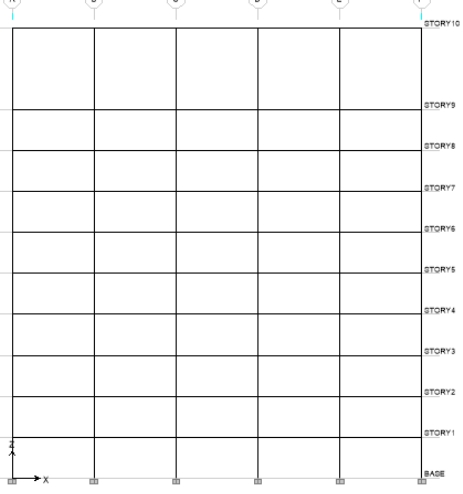

Perbedaan Kekakuan antar Lantai pada Bagian Atas (c)

Gambar 2. Tampak Samping Gedung

2. Tahap Pengumpulan Data:

Pengumpulan data dan informasi tentang struktur gedung yang dijadikan objek pada penelitian ini dilakukan sebelum proses analisis. Data sekunder berupa denah dan mutu material yang digunakan dibuat berdasarkan asumsi peneliti.

3. Tahap Analisa

Ketika semua data-data yang dibutuhkan sudah terkumpul selanjutnya dianalisa. Adapun analisa data yang digunakan adalah mengacu pada standar SNI 1726 2012, SNI 1727 2013, SNI 28472013 dan peta gempa 2017 untuk mengetahui perilaku struktur gedung. Pada pembebanan dimasukan nilai beban hidup untuk bangunan sebesar $240 \mathrm{~kg} / \mathrm{m}^{2}$ berdasarkan Tabel 4.1SNI 1727 $2913^{[3]}$ sementara beban mati dihitung manual oleh program. 


\section{HASIL DAN PEMBAHASAN}

Untuk daerah Jakarta didapatkan nilai $\mathrm{S}_{\mathrm{S}}$ dan $\mathrm{S}_{1}$ sebagai berikut:

$\mathrm{S}_{\mathrm{S}}=0.6$

$\mathrm{S}_{1}=0.35$

Data tanah Tidak diketahui Gunakan kelas situs D, SD

Maka rumus untuk mencari nilai $\mathrm{S}_{\mathrm{MS}}$ dan $\mathrm{S}_{\mathrm{M} 1}$ dan nilai-nilai lain dapat diambil dari SNI 03$1726-2012^{[4]}$

$$
\begin{aligned}
& S_{M S}=F_{a} S_{S} \\
& S_{M 1}=F_{v} S_{1} \\
& F a=1,32 \\
& F v=1,70 \\
& S_{M S}=0,792 \\
& S_{M 1}=0,595 \\
& S_{D S}=2 / 3 S_{M S}=0,528 \\
& S_{D 1}=2 / 3 S_{M 1}=0,397
\end{aligned}
$$

\section{Response Spectra Graph}

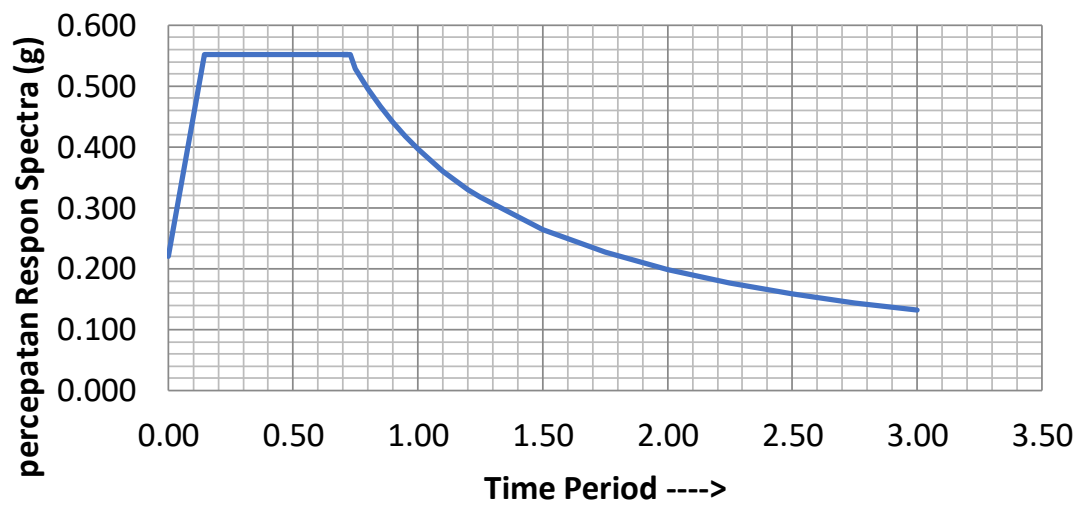

Gambar 3. Kurva Respon Spektrum

Tabel 1. Resume Parameter Seismik Bangunan

\begin{tabular}{|l|c|c|}
\hline \multicolumn{1}{|c|}{ Jenis Pemanfaatan } & $:$ & Perkantoran \\
\hline Kategori Resiko Bangunan & $:$ & II \\
\hline Faktor Keutamaan Gempa & $:$ & 1 \\
\hline $\mathrm{S}_{\mathrm{S}}$ & $:$ & 0.600 \\
\hline $\mathrm{S}_{1}$ & $:$ & 0.350 \\
\hline Kelas Situs & $:$ & $\mathrm{SD}$ \\
\hline $\mathrm{F}_{\mathrm{a}}$ & $:$ & 1.380 \\
\hline $\mathrm{F}_{\mathrm{v}}$ & $:$ & 1.700 \\
\hline $\mathrm{S}_{\mathrm{DS}}$ & $:$ & 0.552 \\
\hline $\mathrm{S}_{\mathrm{D} 1}$ & $:$ & 0.397 \\
\hline KDS & $:$ & $\mathrm{D}$ \\
\hline
\end{tabular}


Tinjauan pertama terkait perilaku gedung yakni terkait dengan periode struktur bangunan gedung. Waktu getar alami struktur dapat diketahui secara otomatis pada program ETABS dengan memunculkan hasil ragam getar yang dapat dimunculkan bersamaan dengan tinjauan mode 1 , mode 2 dan mode 3.

Periode alami struktur diperoleh dari hasil analisis menggunakan software, maka periode alami struktur yang diambil $(\mathrm{T})$ harus ditentukan dengan ketentuan sebagai berikut:

$T a=1,08$ detik

Tmax $=1,52$ detik

$T c=2,01$ detik

Pada tinjauan mode shape diambil tiga tahap, mode 1, mode 2 dan mode 3. Pada suatu gedung yang stabil umumnya mode 1 dan 2 merupakan deformasi ke salah satu arah sumbu (sumbu x atau sumbu y). Sedangkan pada mode 3 bangunan gedung mengalami torsi (puntiran). Mode shape ini merupakan gambaran pada saat bangunan gedung berdeformasi. Sehingga dihindari jika pada mode 1 dan 2 bangunan mengalami puntir.
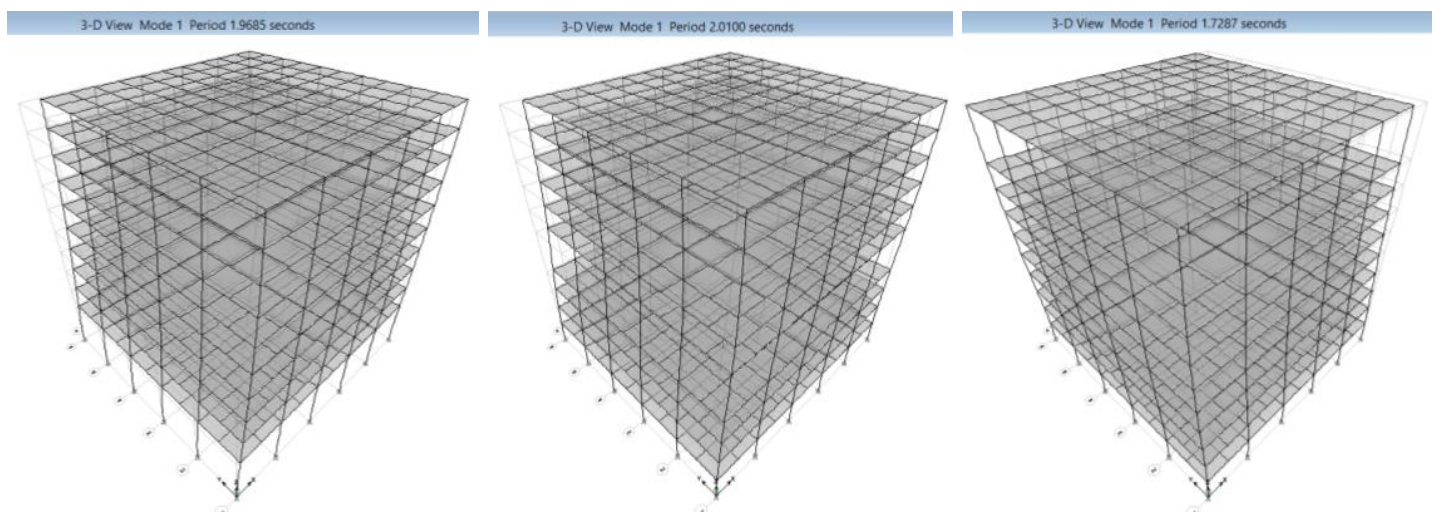

Gambar 4. Mode Shape

Tabel 2. Perbandingan Waktu Getar

\begin{tabular}{|l|c|c|}
\hline \multicolumn{1}{|c|}{$\begin{array}{c}\text { Metode } \\
\text { Perhitungan }\end{array}$} & $\mathrm{X}$ & $\mathrm{Y}$ \\
\hline Nilai $\mathrm{T}_{\mathrm{a}}$ & 1.08 & 1.08 \\
Nilai $_{\max }$ & 1.52 & 1.52 \\
PKBB (cracked) & 1.97 & 1.97 \\
PKBT (cracked) & 2.01 & 2.01 \\
PKBA (cracked) & 1.73 & 1.73 \\
\hline
\end{tabular}

Pemilihan waktu getar mengikuti aturan sebagai berikut:

Jika Tc $>$ Tmax digunakan $\mathrm{T}=\mathrm{Tmax}$

Jika $\mathrm{Ta}<\mathrm{Tc}<\mathrm{Tmax}$ digunakan $\mathrm{T}=\mathrm{Tc}$

Jika $\mathrm{Tc}<\mathrm{Ta}$ digunakan $\mathrm{T}=\mathrm{Ta}^{[5]}$

Maka diperoleh nilai waktu getar $\mathrm{T}=1,52$ detik 
Tabel 3. Perbandingan Waktu Getar

\begin{tabular}{|c|c|c|c|c|}
\hline No & Nama Model & \multirow{2}{*}{ Mode ke- } & \multicolumn{2}{|c|}{ \% PartisipasI Massa } \\
\cline { 4 - 5 } & & & Sumbu X & Sumbu Y \\
\hline 1 & PKBB & 8 & 91.19 & 91.19 \\
\hline 2 & PKBT & 8 & 92.48 & 92.48 \\
\hline 3 & PKBA & 5 & 95.28 & 95.28 \\
\hline
\end{tabular}

Menurut SNI 03-1726-2012 Pasal 7.9.1, yang menyatakan analisis harus menyertakan jumlah ragam yang cukup untuk mendapatkan nilai partisipasi massa ragam terkombinasi sebesar paling sedikit $90 \%$ dari massa aktual yang dimodelkan. Dari Tabel 5.12 terlihat bahwa partisipasi massa sebesar 90\% sudah tercapai pada mode ke-8 pada type gedung PKBB dan PKBT, sedangkan type PKBA tercapai pada mode ke-5.

Tabel 4. Simpangan dan Rasio Simpangan Arah X pada PKBB

\begin{tabular}{|c|c|c|c|c|c|c|c|}
\hline Lantai & $\begin{array}{c}\mathrm{hi} \\
(\mathrm{mm})\end{array}$ & $\begin{array}{c}\delta_{\mathrm{xe}} \\
(\mathrm{mm})\end{array}$ & $\begin{array}{c}\delta_{\mathrm{x}}=5,5 \delta_{\mathrm{xe}} \\
(\mathrm{mm})\end{array}$ & $\begin{array}{c}\Delta_{\mathrm{x}} \\
(\mathrm{mm})\end{array}$ & $\begin{array}{c}\Delta_{\mathrm{a}} / \rho \\
(\mathrm{mm})\end{array}$ & $\begin{array}{c}\text { Keterangan } \\
\Delta<\Delta_{\mathrm{a}} / \rho\end{array}$ & $\begin{array}{c}\text { Drift Ratio } \\
(\%)\end{array}$ \\
\hline 10 & 33000 & 47 & 258.50 & 10.49 & 507.692 & OK & 0.350 \\
9 & 30000 & 45.1 & 248.02 & 14.34 & 461.538 & OK & 0.478 \\
8 & 27000 & 42.5 & 233.68 & 18.55 & 415.385 & OK & 0.618 \\
7 & 24000 & 39.1 & 215.13 & 22.54 & 369.231 & OK & 0.751 \\
6 & 21000 & 35 & 192.59 & 25.95 & 323.077 & OK & 0.865 \\
5 & 18000 & 30.3 & 166.64 & 28.65 & 276.923 & OK & 0.955 \\
4 & 15000 & 25.1 & 137.99 & 30.57 & 230.769 & OK & 1.019 \\
3 & 12000 & 19.5 & 107.42 & 31.57 & 184.615 & OK & 1.052 \\
2 & 9000 & 13.8 & 75.84 & 31.32 & 138.462 & OK & 1.044 \\
1 & 6000 & 8.095 & 44.52 & 44.52 & 92.308 & OK & 0.742 \\
\hline
\end{tabular}

Perpindahan yang terjadi di setiap tingkat struktur dengan metode analisis spektrum respons ragam berdasarkan SNI 03-1726-2012 Pasal 7.9.3 merupakan perpindahan yang diperbesar $(\delta)$. Perpindahan pada tingkat paling atas merupakan perpindahan total struktur bangunan yang ditinjau. Sedangkan simpangan antar tingkat pada suatu lantai diperoleh dari selisih perpindahan (yang diperbesar) lantai tersebut dengan lantai di bawahnya.

Tabel 5. Simpangan dan Rasio Simpangan Arah X pada PKBT

\begin{tabular}{|c|c|c|c|c|c|c|c|}
\hline Lantai & $\begin{array}{c}\mathrm{hi} \\
(\mathrm{mm})\end{array}$ & $\begin{array}{c}\delta_{\mathrm{xe}} \\
(\mathrm{mm})\end{array}$ & $\begin{array}{c}\delta_{\mathrm{x}}=5,5 \delta_{\mathrm{xe}} \\
(\mathrm{mm})\end{array}$ & $\begin{array}{c}\Delta_{\mathrm{x}} \\
(\mathrm{mm})\end{array}$ & $\begin{array}{c}\Delta_{\mathrm{a}} / \rho \\
(\mathrm{mm})\end{array}$ & $\begin{array}{c}\text { Keterangan } \\
\Delta<\Delta_{\mathrm{a}} / \rho\end{array}$ & $\begin{array}{c}\text { Drift Ratio } \\
(\%)\end{array}$ \\
\hline 10 & 33000 & 53.6 & 295.03 & 11.33 & 507.692 & OK & 0.378 \\
9 & 30000 & 51.6 & 283.69 & 15.65 & 461.538 & OK & 0.522 \\
8 & 27000 & 48.7 & 268.04 & 20.69 & 415.385 & OK & 0.690 \\
7 & 24000 & 45 & 247.35 & 26.18 & 369.231 & OK & 0.873 \\
6 & 21000 & 40.2 & 221.18 & 32.57 & 323.077 & OK & 1.086 \\
5 & 18000 & 34.3 & 188.61 & 85.08 & 276.923 & OK & 1.418 \\
4 & 12000 & 18.8 & 103.53 & 36.29 & 184.615 & OK & 1.210
\end{tabular}


Vol. 8, No. 1, Mei 2019, P-ISSN: 2356-1491, E-ISSN: 2655-8211

DOI: https://doi.org/10.33322/forummekanika.v8i1.410

\begin{tabular}{|c|c|c|c|c|c|c|c|}
\hline Lantai & $\begin{array}{c}\mathrm{hi} \\
(\mathrm{mm})\end{array}$ & $\begin{array}{c}\delta_{\mathrm{xe}} \\
(\mathrm{mm})\end{array}$ & $\begin{array}{c}\delta_{\mathrm{x}}=5,5 \delta_{\mathrm{xe}} \\
(\mathrm{mm})\end{array}$ & $\begin{array}{c}\Delta_{\mathrm{x}} \\
(\mathrm{mm})\end{array}$ & $\begin{array}{c}\Delta_{\mathrm{a}} / \rho \\
(\mathrm{mm})\end{array}$ & $\begin{array}{c}\text { Keterangan } \\
\Delta<\Delta_{\mathrm{a}} / \rho\end{array}$ & $\begin{array}{c}\text { Drift Ratio } \\
(\%)\end{array}$ \\
\cline { 1 - 2 } & 9000 & 12.2 & 67.23 & 31.35 & 138.462 & OK & 1.045 \\
2 & 6000 & 6.52 & 35.88 & 24.59 & 92.308 & OK & 0.820 \\
1 & 3000 & 2.053 & 11.29 & 11.29 & 46.154 & OK & 0.376 \\
\hline
\end{tabular}

Tabel 6. Simpangan dan Rasio Simpangan Arah X pada PKBA

\begin{tabular}{|c|c|c|c|c|c|c|c|}
\hline Lantai & $\begin{array}{c}\mathrm{hi} \\
(\mathrm{mm})\end{array}$ & $\begin{array}{c}\delta_{\mathrm{xe}} \\
(\mathrm{mm})\end{array}$ & $\begin{array}{c}\delta_{\mathrm{x}}=5,5 \delta_{\mathrm{xe}} \\
(\mathrm{mm})\end{array}$ & $\begin{array}{c}\Delta_{\mathrm{x}} \\
(\mathrm{mm})\end{array}$ & $\begin{array}{c}\Delta_{\mathrm{a}} / \rho \\
(\mathrm{mm})\end{array}$ & $\begin{array}{c}\text { Keterangan } \\
\Delta<\Delta_{\mathrm{a}} / \rho\end{array}$ & $\begin{array}{c}\text { Drift Ratio } \\
(\%)\end{array}$ \\
\hline 10 & 33000 & 44.5 & 244.70 & 31.90 & 507.692 & OK & 0.532 \\
9 & 27000 & 38.7 & 212.79 & 18.13 & 415.385 & OK & 0.604 \\
8 & 24000 & 35.4 & 194.66 & 21.12 & 369.231 & OK & 0.704 \\
7 & 21000 & 31.6 & 173.54 & 24.40 & 323.077 & OK & 0.813 \\
6 & 18000 & 27.1 & 149.14 & 27.21 & 276.923 & OK & 0.907 \\
5 & 15000 & 22.2 & 121.92 & 29.17 & 230.769 & OK & 0.972 \\
4 & 12000 & 16.9 & 92.76 & 29.85 & 184.615 & OK & 0.995 \\
3 & 9000 & 11.4 & 62.90 & 28.52 & 138.462 & OK & 0.951 \\
2 & 6000 & 6.25 & 34.39 & 23.41 & 92.308 & OK & 0.780 \\
1 & 3000 & 1.995 & 10.97 & 10.97 & 46.154 & OK & 0.366 \\
\hline
\end{tabular}

Untuk sumbu y nilai simpangan bernilai sama dengan sumbu x. Hal ini terjadi karena bentuk geometri bangunan gedung simetris.

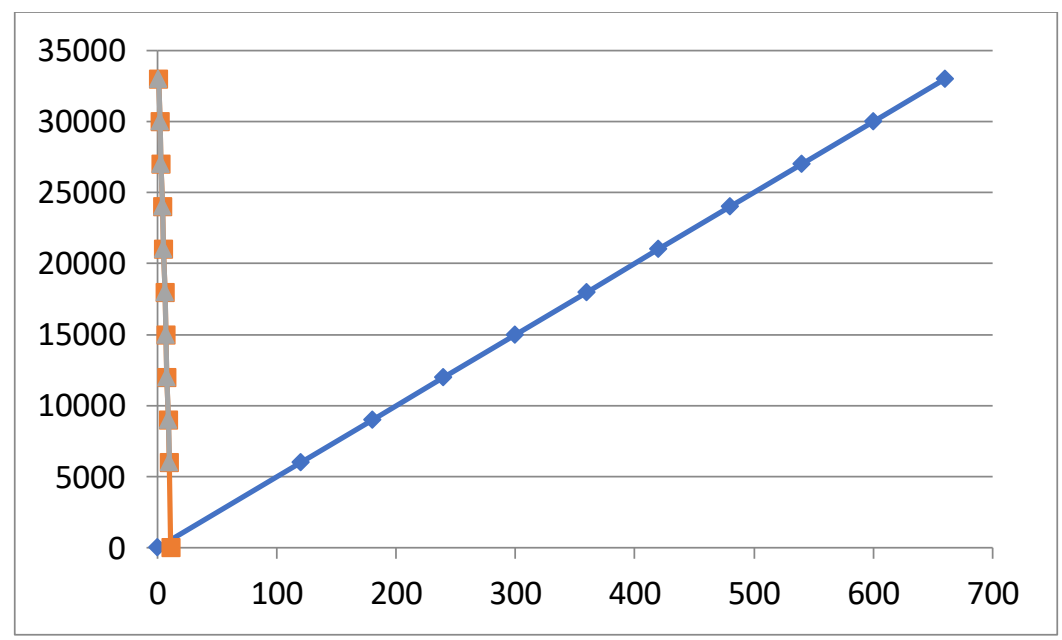

Gambar 5. Displacement Sumbu x dan y Terhadap Displacement Ijin pada PKBB 


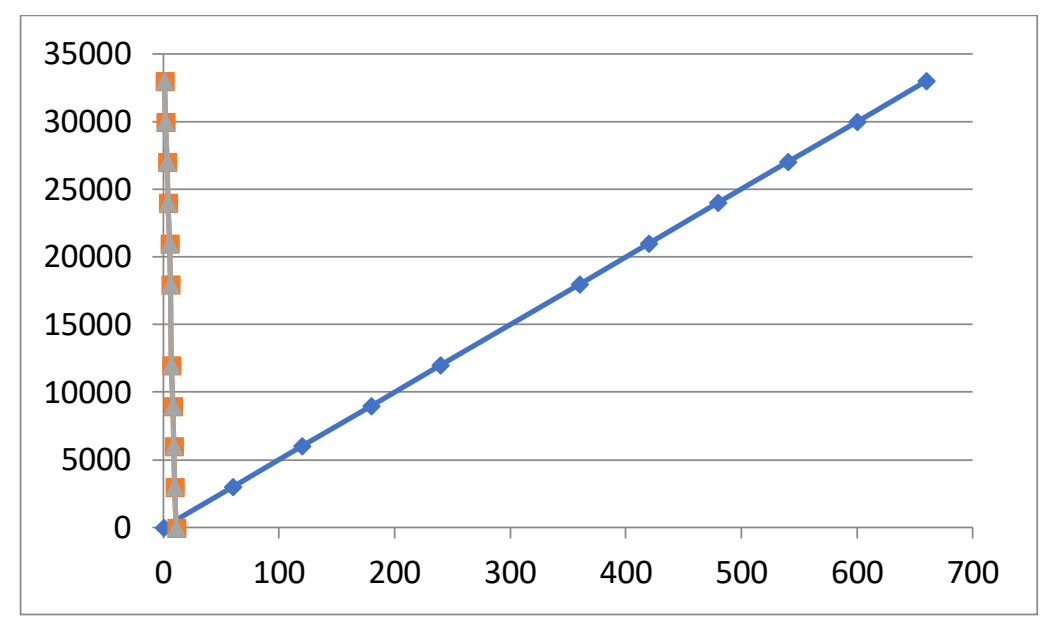

Gambar 6. Displacement Sumbu x dan y Terhadap Displacement Ijin pada PKBT

Simpangan antar lantai tingkat desain $(\Delta)$ tidak boleh melebihi simpangan antar tingkat izin ( $\triangle$ a) seperti yang disebutkan dalam SNI 03-1726-2012 Pasal 7.12.1. Sesuai dalam SNI 03-17262012 Pasal 7.12.1.1, untuk sistem penahan gaya gempa yang terdiri dari hanya rangka momen pada struktur yang dirancang untuk kategori desain seismki D, E, atau F, simpangan antar lantai tingkat desain $(\Delta)$ tidak boleh melebihi $\Delta a / \rho$ untuk semua tingkat.

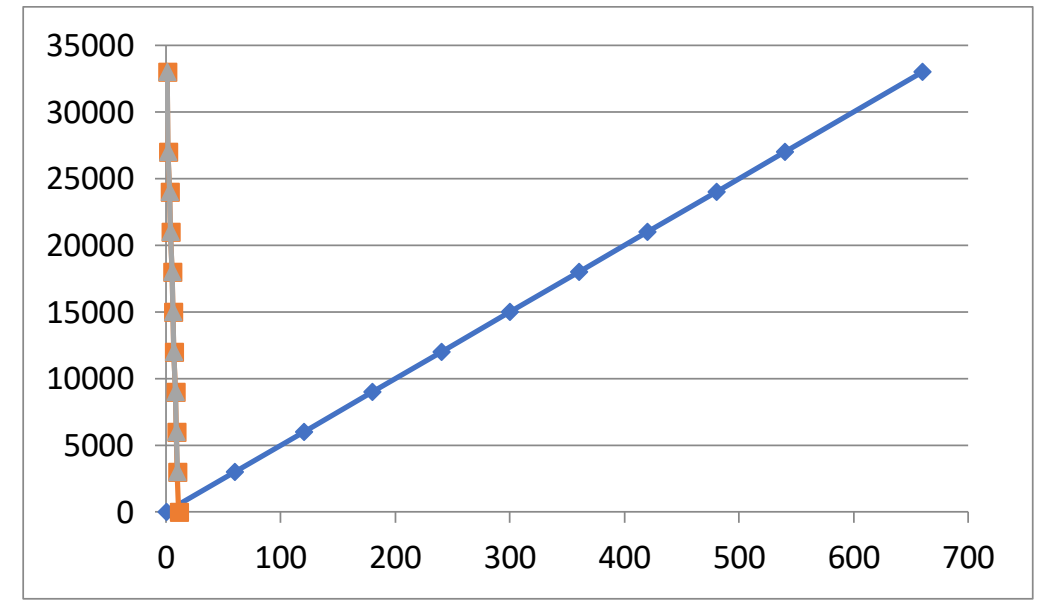

Gambar 7. Displacement Sumbu x dan y Terhadap Displacement Ijin pada PKBA

Untuk garis kurva berwarna merah merupakan displacement terhadap sumbu x. Garis kurva berwarna hijau merupakan displacement terhadap sumbu y. Garis kurva berwarna biru merupakan displacement ijin.Pada Gambar 6-8 terlihat bahwa displacement bangunan gedung masih di bawah displacement ijin.

Perpindahan/simpangan paling besar yang terjadi pada lantai 5 untuk tipe gedung PKBT yaitu dengan kekakuan antar tingkat yang berbeda di bagian tengah gedung. Hal ini perlu menjadi catatan untuk perencana yang ingin membuat bangunan gedung dengan area yang cukup tinggi pada tengah ketinggian gedung. 


\section{KESIMPULAN DAN SARAN}

Kesimpulan yang diperoleh dari hasil penelitian adalah:

1. Periode struktur hasil analisis dengan program dalam kondisi penampang retak ( $c r a c k)$ diperoleh sebesar 2,01 detik.

2. Mode shape untuk ketiga tipe gedung PPKBB, PKBT dan PKBA sudah memenuhi persyaratan dimana pada mode shape 1 dan 2 bangunan gedung mengalami translasi kea rah sumbu $\mathrm{x}$ atau y sedangkan pada mode shape 3 mengalami puntiran.

3. Nilai rasio partisipasi massa yang disyaratkan tercapai pada proesentase $90 \%$ tercapai pada mode shape ke-8 untuk gedung PKBB dan PKBT. Sedangkan untuk PKBA tercapai pada mode shape ke-5.

4. Nilai simpangan untuk ketiga tipe gedung PKBB, PKBT dan PKBA masih dalam batas ijin.

Saran yang dapat diberikan pada penelitian ini:

1. Bentuk gedung dibuat lebih banyak variasi baik seperti ada tidaknya dinding dan bukaan (void) di area tertentu.

2. Perlu ditinjau untuk bangunan gedung yang tidak simetris.

\section{DAFTAR PUSTAKA}

[1] Antonius, dan Widhianto, Aref. 2013. Efek Soft Storey Pada Respon Dinamik Struktur Gedung Beton Bertulang Tingkat Tinggi (199S). Universitas Islam Sultan Agung. Semarang

[2] Siajaya, Kimberly, dkk. 2018. Respons Struktur Gedung Bertingkat Dengan Variasi Kekakuan Kolom Akibat Gempa Berdasarkan SNI 03-1726-2012. Universitas Sam Ratulangi. Manado.

[3] Badan Standarisasi Nasional. 2013. SNI 17272013 Tentang Beban Minimum untuk Perancangan Bangunan Gedung dan Struktur Lain. Jakarta

[4] Badan Standarisasi Nasional. 2012. SNI 17262012 Tentang Tata Cara Perencanaan Ketahanan Gempa Untuk Struktur Bangunan Gedung Dan Non Gedung. Jakarta

[5] Moestopo, Muslinang. Shortcourse HAKI 2012 Struktur Bangunan Baja Tahan Gempa, Jakarta. 